\title{
6
}

\section{I-Entrepreneurship: Changing Lives Through Technology}

\section{Carmen Merab Wamukoya and Amolo Ng'weno}

\section{Introduction}

In today's highly competitive environment, new technologies and ventures have transformed the way we do business. Social enterprises have gained increasing prominence as key players in developing innovative solutions to societal challenges. From a conceptual standpoint, the ideas that drive them bring new approaches to challenges once viewed as insurmountable, and the services they provide can serve as the tools and enablers of the change desired, be it in employment, economic empowerment, and so on. However, social enterprises struggle to remain relevant in a rapidly changing business environment where innovation has become fundamental to their survival and success. Social enterprises therefore require

C.M. Wamukoya $(\bowtie) \cdot$ A. Ng'weno

Digital Divide Data, Nairobi, Kenya

(C) The Author(s) 2017

B. Ndemo, T. Weiss (eds.), Digital Kenya,

DOI 10.1057/978-1-137-57878-5_6 
ICT innovators who can transform ideas into tangible opportunities that produce real results.

This chapter examines the business model of a social enterprise in the ICT sector that uses impact sourcing as a tool for creating employment opportunities. The title "I-Entrepreneurship: Changing Lives through Technology" reflects the chapter's thematic focus on entrepreneurship, and in particular, its examination of entrepreneurship with an impacthence the term i-entrepreneurship. The case study of Digital Divide Data (DDD) Kenya, a social enterprise that provides outsourcing services to clients, serves as a strong example.

The first section provides an overview of social entrepreneurship and impact sourcing. The second section examines the state of unemployment in Kenya and the role of social entrepreneurship and impact sourcing in employment creation. The third section focuses on the business case of DDD Kenya. The chapter closes with a discussion of the challenges and successes experienced by DDD Kenya and a number of recommendations for the country's ICT sector.

\section{The Concept of Social Entrepreneurship}

Social entrepreneurship is at the root of organizations pursuing sustainable and profitable methods of creating social impact. It is a label that merges the excitement of having a social purpose with the model of using innovation and business structures to solve social problems. The phenomenon, which involves combining resources in new ways to create social value, is increasingly popular, gaining attention from both academia and practice (Kupolokun 2014). Although the term "social entrepreneurship" and its current meaning are relatively new, the phenomenon as a practice is not. Both government aid agencies and private foundations have, over many years, supported initiatives, introduced programs, and implemented interventions to attempt to assist impoverished and marginalized groups around the world in innovative ways (Noruzi et al. 2010).

Zahra et al. (2009) posited that social entrepreneurship encompasses the activities and processes necessary to discover, define, and exploit opportunities to enhance social wealth by creating new ventures or 
managing existing organizations in an innovative manner. The idea of enhancing social wealth is what sets social entrepreneurs apart from other types of entrepreneurs, such as those using a for-profit model, whose principal goal is to make profits. At the same time, this definition sets apart social entrepreneurs from not-for-profit ventures and non-governmental organizations. Social entrepreneurs, according to Dees (1998), identify an opportunity to satisfy an unmet need that the existing public and non-public welfare institutions will not or cannot provide. Dees added that for social entrepreneurs, the social mission is explicit and central and that any wealth generated is merely a means to a social end. Austin et al. (2006), similarly, stated that for-profit entrepreneurship has the purpose of maximizing profits and that social entrepreneurship's main objective is to generate and maximize social value.

Social enterprises, therefore, are firms that do business for a social purpose. They link innovation and entrepreneurship with social purpose and seek to be financially sustainable by generating revenue from business activities. Simply defined, social enterprises are organizations seeking business solutions to social problems.

\section{Defining Impact Sourcing}

Impact sourcing emerged from the business-process-outsourcing (BPO) sector, the contracting of specific business processes or operations to a third party. Also known as socially responsible outsourcing, impact sourcing arose as a result of social entrepreneurs in the BPO sector developing an innovative employment model that used technology to hire disadvantaged youth in developing countries. It is the practice of employing people with limited opportunities at the base of the bureaucratic pyramid in BPO centers to provide high-quality, information-based services to domestic and international clients (The Monitor Group 2011). The base of the pyramid is thus made up of individuals from among the 4 billion people earning annual per capita incomes of less than $\$ 1500$ (Prahalad and Hart 2002).

DDD Kenya was one of the early implementers of the social impact model, offering employment in Kenya's BPO industry to people from low-income families. 


\section{Statement of the Problem}

Over 25 percent of the current world's population consists of young people between the ages of 10 and 24 (UNFPA 2014). In Kenya, youth aged 15-34 years constitute 35 percent of the total population (Institute of Economic Affairs 2010) and face a daily struggle in finding work in the context of particularly high unemployment rates (KIPPRA 2013). The bulk of employment opportunity lies in the informal sector, where job stability, reliable income, and career growth prospects are deficient. It is therefore imperative that interventions are put in place to reduce the stark level of youth unemployment in the country.

Fortunately, technological advances are opening new frontiers to tackle the problem of youth unemployment, with ICT emerging as a key sector. Kenya's ICT sector has seen one of the fastest and largest expansions of this sector on the continent, with far-reaching social and economic impacts, such as the creation of digital employment opportunities.

Some of this digital work is carried out through impact sourcing (as defined above). In order to help the huge numbers of disadvantaged youth in the country, social entrepreneurs and their ideas are needed to create social wealth for society across the age spectrum. It is on this concept that DDD Kenya was founded.

This chapter explores DDD Kenya in detail to bring out not only the company's potential, but also the potential for similar social enterprises to create sustainable, formal employment for the innovative but disadvantaged youth of Kenya. It is against this backdrop that social enterprises are seen as potential sources of employment.

\section{DDD Kenya}

DDD Kenya is a social enterprise that generates employment for lowincome, disadvantaged youth by using impact sourcing, professional training, and higher education to give the youth practical, hands-on knowledge in the business and ICT field. DDD Kenya was founded in 2011 as an impact sourcing service provider, with one of us, Amolo Ng'weno, as its first managing director. 


\section{Vision and Mission}

The company's vision is of "a world in which youth develop themselves through education and employment." It is based on four core values-a high-performing organization, a positively motivated workforce, people empowerment, and a collaborative environment. Its mission is to "create better futures for disadvantaged youth in developing countries through employment in our financially sustainable business" (Digital Divide Data 2015a). The idea behind the company was to create an organization that would bring outsourcing services to Africa that simultaneously provided employment opportunities for low-income disadvantaged youth and opportunities to participate in the global economy.

\section{Services}

DDD Kenya offers a range of content-processing services, including digitization, tagging, data entry, records management, Web research, transcription, digital marketing, and e-book conversion to clients both locally and internationally.

\section{Business Model}

DDD Kenya’s business model starts by identifying and recruiting young people from poor and low-income families, mostly from urban slums. The young people selected are recent high school graduates who have achieved good enough grades to enrol at a university but are unable to pursue higher education because of financial constraints. DDD Kenya also recruits people with disabilities, especially those with hearing impairment. These young people go through a rigorous selection process to test their skills. The testing includes computer skills, language skills, speed and accuracy in typing, and math and logic assessments. Home evaluations are also conducted to ensure that the young people are from lowincome families.

After successfully passing all of the assessments, the young people undergo training in computer skills for three to six months. Selected 
trainees who pass the training are employed by the company to work on IT projects as associates. The training equips the associates with ICT skills and enables them to deliver services such as data entry, digitization, document conversion, and Web research.

Associates are then provided with the opportunity to participate in a work-study program where they work on projects while simultaneously studying for a degree over the course of three to four years. The associates in the program have flexible work schedules to enable them to both work and study.

DDD Kenya’s partnership with Kenyatta University, a public university, allows the associates to take classes at the Digital School of Virtual and Open Learning, where they can combine short on-campus sessions with virtual learning. The partnership was formed after a quality assessment of local universities was carried out. The aim was to find a university that was the best value and that had the capacity to work with the associates to develop a four-year course of study that both matched the associates' interests and was relevant to DDD Kenya's program.

DDD Kenya associates typically work at the company for four or five years, during which time they are supported in their pursuit of goals in higher education through partial scholarships, educational loans, and a work schedule that makes time for study. Because of DDD's commitment to its staff's higher education, the associates are required to make a long-term commitment to the company. Unlike other companies in the $\mathrm{BPO}$ sector, DDD does not lay off employees when a project is complete. Clients prefer this work model-especially repeat clients-because they are assured of long-term service. The company therefore attempts to fill its pipeline with recurring projects that employees can work on for a period of several years.

Associates may qualify to receive a partial scholarship from DDD after three months of employment and after they meet university admission requirements. Their education is paid for through a combination of scholarships from the company, their own salaries, and loans. DDD Kenya relies on philanthropic support to cover the cost of its extensive training and scholarships. The government education lender, the Higher Education Loans Board, financed a portion of the tuition costs until 2014, when it changed its policy on supporting private institutions. 
Since then, DDD Kenya has been forced to find social investor lenders to support the cost of this portion of its social enterprise.

After graduating from the university, most DDD Kenya employees find themselves with increased employment opportunities. Based on DDD's experience in Asia going back to 2001, DDD ensures that employees with a university degree and work experience leave the company more attractive to corporate employers than before, with the result that the placement rate of DDD graduates has been nearly 100 percent (Digital Divide Data 2015b).

In this model, high-performing associates often have the opportunity to grow within the company as managers. The typical associate employment period and the time it takes to complete a university degree allow DDD staff members to develop personally while building critical skills and knowledge to ensure continuous improvement in their incomes.

The educational and professional development and maturity of the workforce and the increase in incomes have had a deep social impact. In DDD's experience in Asia, alumni go on to high-skilled positions in which they earn more than two times the average regional wage, enabling them to break the cycle of poverty that often traps their families and communities. They are also able to send other family members to school and raise their households' general standard of living.

\section{Setting Up the Company}

Internet connectivity is at the heart of the BPO sector, and in Kenya, was enabled by the arrival of submarine fiber-optic underwater cables in East Africa in 2010. Faster and cheaper connectivity is a necessary condition for BPOs, although it alone is not sufficient. Other important factorssuch as a favorable regulatory environment, clients, availability of affordable and reliable power, and talented employees - complete the profile of a thriving BPO sector.

The first of Kenya's undersea cables to deliver relatively low-cost, highspeed Internet bandwidth was laid in 2010, paving the way for at least five more. The availability of this bandwidth was one of the factors that made it possible to set up DDD in Kenya — and without which most of its work 
would not be possible. The year 2011 proved to be the right time to establish DDD from a technology standpoint, because the Rockefeller Foundation started to test the question of whether digital jobs drive employment in Africa, and in doing so, gave DDD the grant to set up shop in Kenya. It was one of the Rockefeller Foundation's initial grants in the field of digital jobs, now a core focus of its work. The company also had very strong support from the ICT Board (the government agency charged with developing the ICT sector at the time; it is now known as the ICT Authority), in the form of lending it office space while the company established itself.

Administrative processes, such as registering the company, finding an office space, and working with contractors, were slow but relatively straightforward. There were no bribes, incidents of disappearing files, or long bureaucratic delays. Registration took three months, as was stated.

DDD Kenya launched in April 2011 with 30 associates and 6 managers and administrators. As of June 2015, the company has approximately 500 employees, 400 of which are associates.

\section{Running the Business}

DDD's leaders at the time said they chose Kenya because the existing domestic economy was relatively strong and vibrant, making it possible to develop a BPO model for Kenyans.

However, things did not turn out as expected. When DDD Kenya started, it was anticipated that $80-90$ percent of the business would be from local and government contracts, largely because of the prominence of the BPO and IT-enabled sectors in the Kenyan government's Vision 2030 goals and its sharp focus on the digitization of the economy. BPO is a key government strategy for economic growth and one of six key sectors explicitly highlighted in Vision 2030 (Republic of Kenya 2007). However, in practice, the managing director of DDD found the government to be extremely slow and opaque, and after bidding on many government tenders, the company only won two out of 30.

Eventually, the company also won some additional government-related work. One of its early contracts was with the then-Kisumu Municipal Council (before counties were introduced) and with parastatals (intergovernmental organizations) such as the Kenya National Bureau of Statistics 
and the Kenya Bureau of Standards. However, securing good business domestically did not really succeed as projected.

On the flip side, DDD found that the Kenyan education system was quite efficient, even across the socioeconomic divide. DDD's associates were from some of the worst schools in the city but still turned out to be some of the most impressive graduates. High school graduates from these schools typically have strong English language skills and good problemsolving abilities. They were also work-ready in terms of understanding basic requirements of employment, such as punctuality, following instructions, and meeting deadlines. The associates hired at DDD typically have average grades, rather than top grades, in national exams. Those with top grades are usually absorbed into the government scholarship system, and the rest have to pay their own tuition fees. DDD's prospective employees have high school grades good enough to get into university, but not good enough to obtain a scholarship.

In terms of infrastructure, Kenya does not rank well against a number of global BPO hubs. Electricity, rent, and all the rates for inputs used are higher than in India, Bangladesh, and the Philippines, for example. However, because DDD Kenya is able to work with people of a lower education level, the company is able to be more competitive in certain markets, especially those requiring high mastery of English. DDD Kenya has also found that the types of services the company can offer are more complex and sophisticated than what was expected in the initial business plan.

DDD Kenya competes on quality, delivery, and schedule rather than on price, which has turned out better than expected as a result of the available talent pool. The company's international market is consequently bigger than anticipated, and the company has adjusted itself to the fact that the local market and economy have been disappointingly sluggish.

\section{Challenges of Operating a BPO Company}

Electricity supply is one of the biggest challenges faced by DDD Kenya. Despite the advantageous location of DDD Kenya in Nairobi's central business district and its access to comparatively cleaner power than the rest of the country, frequent power outages persist in particular seasons. The building in which DDD Kenya is housed has a backup generator 
that does not always function during power outages. Electricity is also quite expensive in Kenya, compared with other countries, and accounts for the bulk of DDD Kenya's overhead costs. Electricity is the principal cause of downtime: Outages are extremely disruptive, because without power, operations cannot run, and the company must spend money on backup generators.

The company's second biggest challenge has been the Internet, which, although cheaper and more readily available in Kenya than it used to be, is still not up to the quality and reliability standards required for the industry. Outages, again, are excessively frequent. In 2012, one of the undersea cables out of order, and DDD Kenya's Internet went out for two to three weeks. No work could be delivered to clients; only the work based on the servers could be completed. Although Internet speed has improved since 2012, Internet quality is still a source of frustration, considering that as a business, BPO depends entirely on Internet availability and access.

\section{Successes}

DDD Kenyas main success is arguably the growth of the business: The company has nearly 500 employees and serves an international clientele in a highly competitive market. DDD Kenya has a number of brandname clients and has strong, ongoing relations with many of them. In terms of the Kenyan audience, DDD Kenya has also successfully completed the digitization of the Kenya Law Reports, making the laws of Kenya available - for the first time- to the general public.

In general, DDD Kenya has had many successes by sticking to its social mission-enabling disadvantaged youth to acquire new skills through training, employment, and higher education. Clients are satisfied with the work done, and the company is continually improving its quality and productivity for even better services. DDD Kenya has also won a number of awards - the Disability Inclusion Award 2014, Google Innovation Awards (in Education and Training for 2013-2014 and in Business Process Outsourcing for 2013-2014), CIO 100's Top 100 Firm for Innovative Technology for 2013, ICT Value Award for Excellence in Digital Content Development for 2013, and Connected Kenya Innovation Awards Best in BPO and Outsourcing for 2012. 


\section{Lessons Learned}

DDD Kenya achieved ISO 9001:2008 certification in 2014, marking a milestone in its growth to maturity. ISO 9001:2008 is the International Standard for Quality Management Systems, the most widely used quality management system standard in the world. It provides a framework and set of principles to ensure that effective processes are developed for the management of an organization to consistently satisfy customers and other stakeholders in delivering quality services. ISO certification is also a management method specifying that an organization should have procedures for what it intends to do, should stick to them, and should review them on a yearly basis. The ISO Certification has been invaluable in making DDD Kenya more consistent, reliable, and predictable. It has also enabled a reduction in work-related crises and increased ownership of quality issues among the associates. Stability of processes has also improved as a result of the ISO processes.

\section{The Future}

DDD has an additional small office in Tanzania. The company has also been exploring opportunities in other African countries, including Nigeria. The most growth is expected to come from the international market as the company builds its reputation.

\section{Kenya's BPO Sector: Policy and Recommendations}

Kenya has a large, well-educated English-speaking youth population and a favorable geographical location. There is a growing outsourcing sector and an innovative ICT industry, making it an ideal location for BPO services. The ICT Authority, a government parastatal under the Ministry of Information and Communication, has been actively involved in leading the growth of the information-technology-enabled service (ITES)-BPO sector. Some of the challenges that ITES-BPO companies face-and our recommendations for helping overcome them-include the following: 
- Building of a domestic market Accessing work from both local and international clients remains a problem for Kenyan firms because of high infrastructure costs. This makes it difficult for Kenya to compete for international clients with other cheaper outsourcing destinations, such as India and the Philippines. On the other hand, local demand for BPO services remains low in the private sector. The Kenyan government should provide support in the acquisition of work from its ministries and county governments by, for example, structuring contracts in a way that allows local firms to compete more effectively, including giving hiring priority to local labor.

- Insufficiently comprehensive policy, legal, and regulatory framework There is need for a more comprehensive policy, legal, and regulatory framework to facilitate the ease of doing business and to address issues to do with data protection and intellectual property rights.

- Lack of established industry standards The industry association Kenya IT and Outsourcing Society (KITOS) should develop clearer standards and codes of conduct and should liaise with government agencies to ensure that these standards are bolstered by relevant legislation. This would also improve worker protection, a key concern in certain parts of the BPO industry.

- Insufficiently widespread marketing of BPO services The government has been considerably successful in marketing the IT sector, but more effort is required to market the BPO sector. An increase in local and international awareness of the BPO sector and services could increase demand for services. The government should continue branding the ITES-BPO sector to increase general awareness and to showcase the opportunities available. It should also actively promote Kenya as a destination for BPO services at international forums and conferences and make efforts to counter the bad press that has arisen from the likes of terrorist incidents and other challenges in the recent past.

- Lack of a BPO incentives structure to motivate BPO companies To attract more clients and investors, the government should develop an incentives framework, including, for example, tax incentives, training subsidies, and youth employment incentives.

- Lack of training in basic BPO skills Although there are ambitious plans to develop BPO curricula at several universities, simpler skills such as typing and Excel are not emphasized in the current education system. The government and KITOS should establish a basic 
certification that would allow new associates to enter their first employment with proof of basic skills.

- Shortage of verifiable information and statistics on the BPO sector There are insufficient data on ICT. Industry statistics are needed to establish the size of the sector, key players, GDP contribution, growth rate, services offered, and the number of people employed - so as to monitor the progress being made and inform evidence-based policy decisions.

- Unreliable infrastructure Kenya has inconsistent electricity supply and unreliable telecommunication infrastructure despite recent and ongoing substantial investments by both the private and public sectors. For the BPO industry to grow successfully, investment should continue and the relevant regulators should pay particular attention to reliability and uptime, not just to access.

Despite these challenges, Kenya still has great potential to scale up the $\mathrm{BPO}$ sector and attract investment as a BPO destination. Government and industry efforts should concentrate on addressing the stated issues of attracting investors, developing a comprehensive policy, legal, and regulatory framework, establishing industry standards, developing an incentives structure to motivate BPO companies, preparing industry statistics on the $\mathrm{BPO}$ sector, and providing reliable infrastructure to create a more conducive environment for BPO investment and growth.

These recommendations, if implemented, would greatly strengthen the $\mathrm{BPO}$ sector in Kenya. Kenya has a growing BPO industry, but the market remains largely untapped because it is still a comparatively more expensive destination. Although connectivity continues to improve gradually, policy adoption still tends to be slow. Vision 2030 guidelines are directing policymaking and helping to create awareness about the opportunities in impact sourcing. However, there is still room for the national government and counties to do more for Kenya to become the "top BPO destination in Africa."

\section{References}

Austin, J., Stevenson, H., \& Wei-Skillern, J. (2006). Social and commercial entrepreneurship: Same, different, or both? Entrepreneurship Theory and Practice, 30, 1-22. 
Dees, J. G. (1998). The meaning of social entrepreneurship: Draft report for the Kauffman Center for Entrepreneurial Leadership. Accessed 22 Feb 2016. Available at: https://entrepreneurship.duke.edu/news-item/the-meaning-ofsocial-entrepreneurship/

Digital Divide Data. (2015a). Vision and mission. Available at: http://www. digitaldividedata.com/about/ddd-africa. Accessed 21 Feb 2016.

Digital Divide Data. (2015b). 2014 Impact report. Available at: http://www. digitaldividedata.com/sites/default/files/case_study/DDD\%202014\%20 Impact\%20Report.pdf. Accessed 21 Feb 2016.

Institute of Economic Affairs (2010). Kenya youth fact book. London: Institute of Economic Affairs.

Kenya Institute for Public Policy Research and Analysis (KIPPRA) (2013). Kenya economic report 2013. Nairobi: KIPPRA.

Kupolokun, O. (2014). For-profit social entrepreneurship: A study of resources, challenges, and competencies in UK. Doctoral thesis, Goldsmiths College, University of London, London.

Noruzi, M. R., Westover, J. H., \& Rahimi, G. R. (2010). An exploration of social entrepreneurship in the entrepreneurship era. Asian Social Science, 6(6), 3-10.

Prahalad, C. K., \& Hart, S. L. (2002). The fortune at the bottom of the pyramid. Strategy+Business, 26(1), 2-14.

Republic of Kenya (2007). Vision 2030: A globally competitive and prosperous Kenya. Nairobi: Government of Kenya.

The Monitor Group (2011). Job creation through building the field of impact sourcing.

UNFPA (2014). State of the world population. New York: United Nations.

Zahra, S. A., Gedajlovic, E., Neubaum, D., \& Shulman, J. (2009). A typology of social entrepreneurs: Motives, search processes and ethical challenges. Journal of Business Venturing, 24(5), 519-532. 


\title{
Conversation \#6
}

\author{
How Technology Makes \\ Farming Sexy Again
}

\section{Su Kahumbu Stephanou of Green Dreams Tech Ltd.}

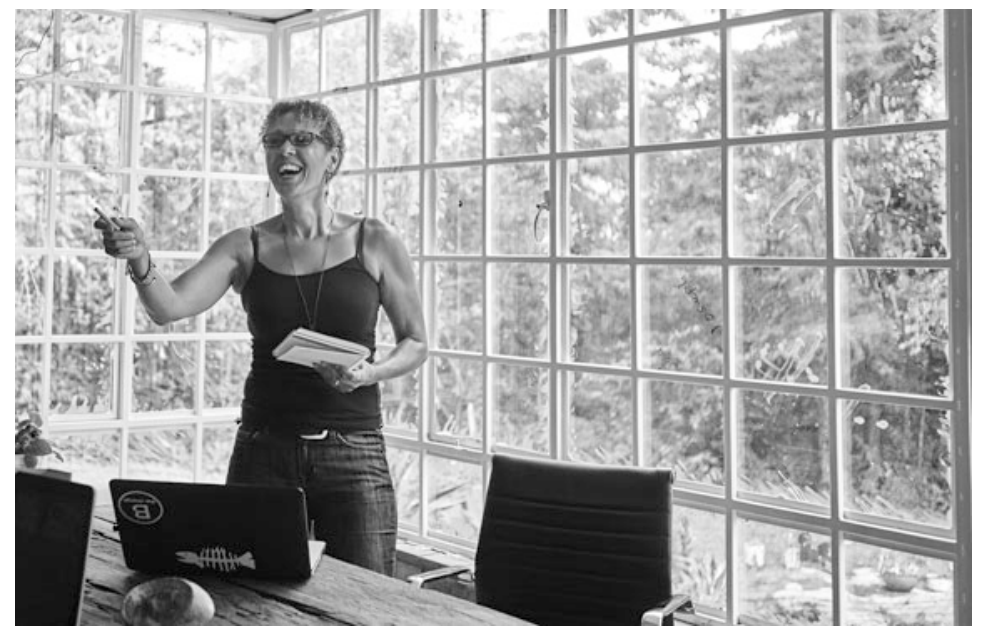

Social entrepreneur Su Kabumbu Stephanou is a passionate organic farmer and the founder and Chief executive officer (CEO) of Green Dreams Ltd. and Green Dreams Tech Ltd. She is a pioneer in the organic industry in Kenya, working with smallholder farmers for more than 15 years. Her goal is to inspire, enable, and support farmers across Africa as they engage in sustainable agro-ecological agriculture in order to alleviate poverty and to contribute both to food security and to a sustainable environment. Through Green Dreams Tech Ltd., she developed the award-winning mobile phone application iCow 
(www.icow.co.ke), winner of the first Apps4Africa Award, winner of the Vision 2030 Innovation Award for Agriculture in Kenya, and finalist in the Innovation Prize for Africa 2012. iCow today serves hundreds of thousands of farmers across Kenya. Su sits on the advisory boards of a number of global and local agricultural initiatives and is a TED Global Fellow.

\section{What is particularly exciting about being an entrepreneur and why do you consider yourself as one?}

I believe you cannot make entrepreneurs. They are born this way. It is something in their DNA that creates this particular insatiable drive that is so characteristic of an entrepreneur. True entrepreneurism cannot be forced through education, only honed by it. I think that is one of the reasons why we see high failure rates among businesses and start-ups. Not everyone is born to be an entrepreneur. One key factor that differentiates entrepreneurs from other people is passion. Entrepreneurs will go beyond the call of the business plan and the idea of making money. They will knock their heads against the wall trying to solve a problem, because they have become extremely passionate and obsessive about it, and they will keep on going at it against all odds.

Sometimes I look down my career path and question whether it could have been different. The answer is always the same. No way. No regrets, and no brakes. There is nothing in me that would allow me to stop. I cannot see into the future, but I just know that this is what I am made to do, and that makes me a passionate entrepreneur. I believe in what I do. I am driven by an unseen and uncontrollable force, and I love it. I call this the entrepreneurial spirit. It is captivating and hugely exciting. A lifelong rollercoaster ride.

As an example, I was not educated or trained in agriculture at all, and I do not even think that my core is really about agriculture. I think just like many entrepreneurs: We look at the world through a lens of connecting dots and are able to see many more dots than other people. Entrepreneurs pick up ideas from many different spaces, sectors, and experiences and manage to put them together into something new. Whether I am watching a movie or walking down the road and whether the movie is about science fiction or about wildlife, I am always picking up new ideas that I can bring 
back into my context. It is a constant awareness that allows new light bulbs to light up inside you-hugely challenging and hugely satisfying.

My first job was in a bookshop, where I learned early on that I was not an employable person. I found it deathly boring. I realized very early on that I could not be employed and that I like to charter my own course. That I like control and like to be in the driver's seat. Looking back, this determined streak was evident even at 18 when I left school to join a band. This period gave me the creative space to learn how to earn my own living, despite its ups and downs. Coming from a very creative family, I found it easy to start income-generating projects and did everything from making wooden key chains to selling pies and biscuits. I set high standards for myself in everything I did. They had to be the best. All or nothing.

I was always making something and selling something while I was doing music. Later, I married and moved to South Africa with my husband and two children to join my sister-in-law in business. It did not last very long, because I found it impossible follow someone else's instructions while feeling that mine were more creative, constructive, and productive.

\section{You started your entrepreneurial journey with the organic vegetable company Green Dreams before you ventured into technology. Tell us how it all started!}

It started with a hydroponic farm visit in South Africa where lettuce for the fast-food industry was grown. In hydroponics, you do not use soil. The system used plastic-lined troughs and small stones as a growing medium. It is a chemical- and pesticide-intensive process aimed at growing high yields in minimum spaces. It really triggered my interest, and I began to imagine its value in our slums in Kenya. I am not quite sure whether I actually came into agriculture with an interest in agriculture or because of the curiosity for something that just seemed so cool and different.

We returned to Kenya and tried to put up demo sites — and failed abysmally because we knew nothing about the real requirements of plants. We were not from an agricultural background at all, so in the beginning, we faced lots of failures. I have learned to think of my failures as "learnings" and, like many entrepreneurs, expect a continual stream 
of them going forward. The talent of an entrepreneur is really to fall forward, often. The crops were infested with pests and disease, failing to grow until we got rid of the hydroponics and put them into soil with drip irrigation in my mother's garden. In no time, we ended up with a whole bunch of lettuce that we then had to sell with the added value of being cleaned and packaged. That is how Green Genes started which turned later into Green Dreams. We (my family and I) crafted little labels, stuck them on the bag, washed the lettuce, and bagged it - and they sold like crazy. We continued developing mixed lettuce bags that were popular in South Africa but nowhere to be seen in Kenya. As the demand grew, we started to involve out-grower farmers in the vicinity, and eventually we had our products in the supermarkets, airlines, and hotels.

My role required managing a growing team as well as a growing range of products and customer preferences. After two years and a close call where my mother became quite ill after being exposed to a lethal pesticide, we changed our production system from conventional, using agro pesticides and fertilizers, to organic production, which is better for our producers, customers, soils, and the environment.

\section{You worked intensively with Kenyan farmers. Can you give us an idea on what farming is like in Kenya today?}

As my business grew, I started to look at widening my supply chain and increasingly worked with smallholder farmers as out-growers. A tragic instance where my mother got caught downwind with pesticide and became very sick shifted my mindset about safe food production completely away from industrial production to organic farming. Producing safe food—called organic at the time (we call it agro-ecological today) is, of course, food that you grow without the use of artificial or synthetic pesticides or toxins. It required educating my entire supply chain on how to produce organically.

In Africa, being a farmer is quite different from the heavily subsidized, trained, and incentivized farmer from the West. Here, the majority of farmers are people who just try to eke out a living on their land and sometimes sell some of their produce in the market. Unlike in developed countries, farmers here were not growing only wheat or only maize. Smallholder farmers grow 
on average around 5-8 different crops and vegetables, an assortment of root vegetables, brassicas, fruit, and grains as well as keeping up to four different species of livestock - cows, chickens, goats, sheep, and pigs. Production of this diversity requires a lot of knowledge, and in Kenya we do not have an adequate extension system in place that can deliver so much diverse knowledge at scale. The risks in agriculture are high, and farmers cushion their risk through diversification. To reduce their risks further, they need in-depth knowledge on each of the crops and livestock they keep. The problems the farmers were facing became more obvious to me as I trained them on the product requirements for my business. Lack of knowledge was manifesting itself in reduced yields, poor quality crops and livestock, low farmer income, and poorer and older farmers, because young people were not interested in working in such a tough industry. I also began to realize how the problem was much bigger than just in the organic sector, but countrywide. Where 80 percent of the food that comes to market in Kenya is produced by smallholder farmers, it was becoming apparent that the low-yield production from farmers plus the vagaries of climate change would soon be affecting food security for the nation. This began to concern me and at the same time interest me in creating a solution to this humongous problem.

\section{How can small-scale farming be turned into a market opportunity?}

To begin with, we need to understand the parameters within which small-scale agriculture exists and the opportunities that are available when we combine it with technology and other factors.

As a nation of tribes, we are connected to our land-where the biggest asset we have is our land. Culturally, we inherit and pass on land to family members. This has resulted in many land subdivisions, with the result that most farmers or landowners own relatively small parcels of land-meaning that a model for increasing food yields and quality in Kenya must take this fact into consideration.

While the biggest employment opportunity in Kenya lies in agriculture, young people are the targeted segment of the population to move agriculture forward. The challenge therefore is to attract young people into agriculture, given the many obstacles—small parcels of land, land ownership issues, lack of access to capital, lack of access to knowledge 
(production and processing as well as other opportunities in the various agricultural value chains), and lack of access to markets. Parts of this complex puzzle have been solved in other countries, such as China, where the use of micro mechanization has tackled the problem of small land-parcel sizes. In Kenya, we do however have the advantage of mobile money. When we couple mobile money, a large youth bracket, micro mechanization, millions of landowners, and millions of consumers, we can create exciting hybrid businesses models and industries that create wealth and build the economy. In so doing, we can build food security not only for Kenya, but for Africa.

One model could be contract farming, where young people_-through consultancies and businesses - till the land and install drip irrigation for landowners, who then buy the crops for value addition, processing, and marketing. This model is customizable to Kenya and the complexities mentioned above about land and culture, and it is also much more equitable and better for the country and its people as a whole.

The challenge is to make these kind of opportunities appealing to young people by, for example, empowering them with knowledge on the availability of various agri-technologies — such as drip irrigation, shade netting, micro mechanization, and so on- so that they can build, collaborate, and even create businesses with landowners.

There is a more efficient way of farming in Kenya, if we combine our cultural inheritance system with the power of technology. But we have not yet fully figured this out.

\section{What are some examples and success stories of new ways of farming?}

There are many ways to make agriculture sexy again. First of all, let us look at what makes it unsexy.

Farming is back-breaking hard work. At the smallholder level, it is mainly manual and is fraught with risks, some manageable and others completely out of one's hands (e.g., the weather). A farmer's life is made even harder because he or she is bound to the farm through weekends and holidays and typically does not have a pension or healthcare or livestock 
insurance. Although farmers perform the most important function of any sector in a country - that is, to produce food-in Africa they are typically ignored and left to their own devices. There are no guarantees in farming. The challenge thus is to turn this around to attract the youth to get engaged in the sector.

During the post-election violence of 2007-2008, I was asked to support a group of young people in Kibera who had been thugs but decided to turn a garbage site into an organic farm. In three days, the land went from garbage to soil as the garbage was removed. One hundred days later, the group was feeding their families and selling surplus vegetables to families in the slum. The success was remarkable because the job was not backbreaking. What made it easy was the use of drip irrigation and a planting system that allowed for an easy way to grow a multitude of vegetables and crops while reducing the likelihood of fungus and other diseases. Making these technologies visible to these young people allowed them to see the benefits and opportunities of making a living from agriculture.

Look at one of our customers on iCow, for example. We stumbled across Aaron when we conducted research on farmers using the iCow platform. He initially went to IT school and tried to find a job in Nairobi. He could not get a job and decided to go back home to his rural area. Here his mom was growing broiler chickens, and he came back to join her in production. Once he made his plans clear, she said, "Not unless you do it with iCow!" - an agricultural information service that you subscribe to, to help enhance your productivity. She learned how to do it the right way, and because she experienced it by retrieving information from us, she was in a better position to produce chickens. He followed her advice, and by the time we got to interview him he was already on his ninth yield of chickens - and his vision of opening up the equivalent of a Kenchick or a KFC has unleashed his entrepreneurial spirit. He is a wonderful example of the kind of young person who learns the nitty-gritty details from the ground up and becomes an expert in his field, which then allows him to look for new opportunities to create value. For him, agriculture is sexy, because he has the ability to grow his knowledge and has affordable tools at his fingertips to do so. He is automatically ahead of a farmer who delves into chicken production without knowledge. 
I envision the following model for Kenya: Imagine 40 plots, each a quarter of an acre in size, cultivated by elderly people in a rural area. Tough work. Low yields. Now imagine an organized crop-contracting service run by young people, providing these farmers with services to plow their land, install drip irrigation, and market their yields. The young people go a step further and engage in value addition as well as wholesale and retail sales. Meanwhile, payments are organized over mobile money. And retail outlets passionately market "Buy Kenyan, for Kenya," supported by government policy. It can happen! These kinds of approaches take into account our local customs, our opportunities, and our national needs.

\section{What exactly is the service that $\mathrm{iCow}$ is delivering?}

iCow is a mobile phone-based agricultural platform that provides farmers with a variety of products that helps them build agricultural knowledge, reduce risks, and connect with their relevant agricultural experts.

When I designed iCow, the target user I had in mind was a smallholder farmer in Kenya. Sustainability of the product was based on a payment model by the farmers. Starting with a payment model from day one enabled us understand and build products that were of value to our users. It is difficult to evaluate a free product.

The information products on iCow are either subscription or pay-asyou-go products. The farmers receive their content to queries and education in SMS format that they pay for. What we are seeing in the field is that farmers archive the SMS content in exercise books for future reference.

One of the tools on iCow is the cow calendar. The farmer can register his pregnant animal and receive SMS messages about the specific point in the gestation of the animal so that he is aware of what he needs to think about next. He needs to feed the animal differently during this period, which is crucial for future health and milk productivity. Currently, the average Kenyan dairy cow produces six liters of milk a day. The exact same breed produces 40 to 60 liters a day in Europe. They are bred for heavy, high-intensity feeding, and in Kenya they are kept in small farms. There is still unmet potential as well as a disconnect between production systems and animal phenotypes. 
We also have chicken calendars on iCow that help farmers with chicken breeding for the broiler market. The broiler's lifespan is only about six to seven weeks, so farmers register the day they get their day-old chicks, and we drip feed SMSs with a comprehensive approach to best broiler practices. These include feeding, vaccinations, hygiene, brooder temperatures, and much more.

Another tool is for soils, enabling farmers to learn about the general soils in their area and advising them to have their soils tested while also providing them with contacts for soil testing-service providers. We have uploaded the entire national soils database on the platform, allowing farmers to get loads of information on the particular soil quality in their area and recommendations that allow them to improve their soil quality. Knowing your soil quality or the specific problems of your soil allow you to make the right decisions about fertilizers - whether to use natural or synthetic and in what volume. Our objective is to enhance the knowledge of the farmer so that he can make informed decisions and decisions he can afford.

\section{How did you scale iCow so that it could reach the broad mass of farmers in Kenya?}

Initially, I had wanted to keep iCow agnostic across the three mobilenetwork operators, because I did not want to push the decision as to which network to choose onto the farmers. Later, because of our marketing strategy, we were fortunate enough to form a partnership with Safaricom. In the early phase, we did a lot of prototyping, tweaking, and product development, resulting in a good product that users liked. Our data showed that within three months of being on the iCow platform, farmers were beginning to see an increase in yields of between two and three liters of milk per animal.

Our exclusive agreement with Safaricom gave us access to their marketing machinery and we used a variety of different channels to market iCow. The response was astounding. At one point between 8000 and 14,000 farmers signed up on our platform every day, and eventually our system crashed. Once we hit 182,000 users in our database, we realized that our back end was not up to the task. Messages did not get sent, and our system became unreliable. We had to redesign iCow in its entirety. 
During the one and a half year redesign phase, we added some new tools that came from both farmer feedback and my own experiences as a farmer. These were designed to tackle some of the main pain points in farming. In the redesign of iCow, with help from our partners The elea Foundation for Ethics in Globalisation and Accenture Switzerland, we increased our scope to cover multiple languages and territories, as by this time, we had also received many requests from countries in Africa, Asia, South America, and North America that wanted to use various components of iCow.

We have a variety of feedback loops with farmers that make product development demand driven and easier. So right now, 56,000 farmers use our SMS service three times a week. They are from over the entire country and range in age from 82 to early teens. Interestingly, the average age of farmers as reported by the government is 55 . Once we started to do our marketing via Safaricom — using SMS — our average age dropped significantly, and according to our latest survey it is 33 years. With Safaricom, we managed to reach out to a whole new customer segment, which is incredible. We now know that farmers can afford a certain amount of SMSs in a week and are also willing to pay for it as long as they realize impact. My next challenge is to see whether we can provide more information in a shorter time span to create impact faster.

\section{Thank you, Su!}

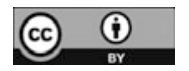

This chapter is distributed under the terms of the Creative Commons Attribution 4.0 International License (http://creativecommons.org/licenses/by/4.0/), which permits use, duplication, adaptation, distribution and reproduction in any medium or format, as long as you give appropriate credit to the original author(s) and the source, provide a link to the Creative Commons license and indicate if changes were made.

The images or other third party material in this chapter are included in the work's Creative Commons license, unless indicated otherwise in the credit line; if such material is not included in the work's Creative Commons license and the respective action is not permitted by statutory regulation, users will need to obtain permission from the license holder to duplicate, adapt or reproduce the material. 